\title{
Membedah Diskursus Modal Sosial dan Gerakan Sosial: Kasus Penolakan Pabrik Semen di Desa Maitan, Kabupaten Pati
}

\section{Priyatno Harsasto}

Departemen Politik dan Pemerintahan, Universitas Diponegoro

\begin{abstract}
Abstrak:
Modal sosial adalah hasil dari gerakan sosial dan sebaliknya. Teori gerakan sosial seperti model mobilisasi sumber daya mencoba menjelaskan anatomi aksi kolektif dalam konteks sistem politik modern di Barat. Teori ini dapat digunakan untuk mengurai aksi kolektif secara umum tetapi mungkin tidak cukup untuk menjelaskan gerakan sosial di pedesaan di Indonesia di bawah rezim politik demokrasi transisional. Dalam politik pedesaan Indonesia kekinian, gerakan sosial yang melibatkan kelompok petani seringkali kandas di tengah jalan. Gerakan petani di desa Maitan, Pati, Jawa Tengah menggambarkan bagaimana jejaring sosial membentuk aksi kolektif. Tetapi, jejaring horizontal di antara para penolak sendiri tidak cukup berhasil untuk memperkuat jejaring vertikal. Sementara, keberhasilan advokasi seringkali tidak bisa mengabaikan hubungan yang kuat dengan para birokrat pengambil keputusan.
\end{abstract}

\section{Keywords:}

gerakan sosial; modal sosial; jejaring horizontal, dan jejaring vertikal

\section{Pendahuluan}

7 roses desentralisasi yang demokratis seringkali melibatkan bargaining politik yang intensif dan pembuatan koalisi diantara elit dari berbagai level pemerintahan. Desentralisasi diharapkan meningkatkan tidak saja efisiensi birokrasi tetapi juga akuntabilitas pemerintah. Namun apabila kita memperhatikan desentralisasi dari pandangan pemerintah lokal, desentralisasi memiliki makna yang berlawanan. Dengan memberikan otonomi yang lebih besar, pemerintah lokal bebas untuk melakukan apa yang mereka pandang lebih sesuai dengan kondisi lokal. Proses desentralisasi memang dapat mentransformasikan peran pemerintah lokal dan regional, namun kekuatan sentralistis yang telah membelenggu di masa lalu tidak mudah ditinggalkan dan masih menjadi cara kerja elit. Lebih lanjut, pada wilayah lain pemerintahan sub-nasional, desentralisasi telah memperkuat dan meghidupkan struktur kekuasaan oligarkis lokal yang sebetulnya didesain untuk disingkirkan (Aspinall, 2014; Fealy, 2013). Media massa banyak melaporkan kasus-kasus korupsi, intimidasi, dan 
politik uang pada pemerintah lokal, yang menobatkan kepala daerah sebagai tokoh yang sangat kuat secara politik (raja kecil).

Kombinasi reformasi yang berorientasi pasar dan desentralisasi nampaknya telah mendorong pemerintah lokal untuk berperilaku yang berorientasi kepentingan sempit yang diwujudkan dengan eksploitasi sumberdaya lokal yang berlebihan. Tentu saja hal ini bertentangan dengan kepentingan masyarakat. Inilah yang menyebabkan munculnya perlawanan dari masyarakat untuk mempertahankan kepentingan ataupun hak mereka. Kasus perlawanan masyarakat di Banyumas yang berkaitan dengan penambangan pasir besi (Alfirdaus, 2011), perlawanan masyarakat Rembang menentang penambangan di wilayah resapan air (Suharko, 2013), dan perlawanan masyarakat Tabanan menentang reklamasi (Hapsari,2014), hanya beberapa kasus yang disebutkan di sini. Gerakangerakan ini tidak sama dengan reformasi politik 1998 yang merupakan gerakan demokratisasi, perlawanan akar rumput terutama ditujukan kepada pemerintah lokal atau perusahaan yang beroperasi di wilayah tersebut, dan mereka lebih memusatkan perhatian kepada masalah ekonomi atau sosial tertentu daripada tuntutan politik yang abstrak.

Penelitian ini merupakan upaya untuk memahami gerakan sosial petani kecil di Desa Maitan Pati. Seperti penelitian-penelitian gerakan akar rumput sebelumnya, penelitian ini juga membahas mengenai perlawanan masyarakat desa terhadap pelanggaran terhadap hak-hak hakiki mereka. Suatu gerakan sosial yang pada dasarnya merupakan upaya menghadirkan proses partisipatoris dalam pengambilan keputusan. Dalam penelitian ini gerakan sosial tidak dilihat sebagai organisasi, tetapi dipahami sebagai mobilisasi network. Dengan menggunakan metode studi kasus, penelitian ini dengan hati-hati berusaha menyingkap bahwa suatu gerakan sosial terjadi dalam lingkungan sosial tertentu, menciptakan kerangka umum gerakan dan mempengaruhi kemungkinan munculnya tindakan kolektif. Mengikuti pendapat Stake (1994: 237) studi kasus merupakan proses belajar sekaligus produk hasil belajar yang dilakukan peneliti. Makin spesifik, unik dan khusus obyek studi, makin besar manfaat yang didapat.

Desa Maitan merupakan salah satu desa di Pati yang wilayahnya akan didirikan pabrik semen. Masyarakat tidak menginginkan desa mereka menjadi wilayah pendirian pabrik semen dengan banyak alasan. Apalagi Bupati Haryanto dalam kunjungannya selalu mengatakan bahwa tidak akan ada pendirian pabrik semen di Maitan. Janji ini tidak dipenuhi oleh Bupati Haryanto dan ia selalu mengelak ketika masyarakat menanyakan tentang janjinya tersebut. Ketidaksetujuan terhadap pendirian pabrik semen yang semula hanya berupa gunjingan berubah menjadi protes yang dilakukan oleh sekelompok kecil masyarakat. Gerakan protes ini kemudian membesar ketika mulai melibatkan kekuatan anti pabrik semen dari luar desa Maitan. Bagaimana perlawanan sosial digalang menjadi gerakan sosial akar rumput di Desa Maitan? Bagaimana mereka menjalankan tindakan kolektif melalui hubungan-hubungan horisontal maupun vertikal dengan orang ataupun organisasi lain? Strategi apakah yang digunakan dalam mengkonsolidasikan gerakan untuk memperluas cakupan partisipasi masyarakat sekaligus memperkuat kelembagaan gerakan?

\section{Kajian Gerakan Sosial dan Perlawanan Kolektif}

Pada dasarnya teori-teori gerakan sosial pada umumnya merupakan upaya untuk menjelaskan bagaimana suatu perlawanan kolektif dilakukan. Pada sisi yang lain munculnya teori gerakan sosial baru merupakan bagian dari kebangkitan perspektif budaya dalam ilmu sosial (McAdam, 1996: 27). Teori-teori ini dibangun berdasarkan 
refleksi atas konteks sistem politik liberal negara-negara Eropa dan Amerika; masih diragukan memiliki kemampuan eksplanasi yang mencukupi untuk menjelaskan fenomena perlawanan sosial di Indonesia yang terjadi dalam konteks kekuatan oligarki lokal. Di kawasan perdesaan Indonesia saat ini, gerakan sosial akar rumput dilakukan untuk mempertahankan hak-hak kolektif yang dilakukan oleh kelompok petani. Karakteristik gerakan sosial akar rumput semacam ini berbeda dengan karakteristik gerakan sosial di Eropa dan Amerika. Gerakan sosial di barat dapat diklasifikasikan ke dalam 4 model: gerakan transormatif, gerakan reformatif, gerakan redemtif, dan gerakan alternatif (Giddens, 1998: 511-513). Semua model tersebut merupakan tindakan kolektif yang berupaya menggeser norma-norma, sikap dan perilaku masyarakat pada level makro ataupun perbaikan mikro pada level individual. Sebaliknya apa yang terjadi di Indonesia saat ini lebih merupakan upaya kolektif warga untuk mempertahankan hakhak sipil mereka atau menemukan solusi masalah sosial pada tingkatan kelompok.

Penelitian yang dilakukan oleh Alfirdaus (2011, 2014) mendapatkan temuan penting dari kajian terhadap tiga kasus di tiga daerah yang berbeda tentang kebutuhan bagi gerakan sosial akar rumput untuk lebih menekankan advokasi diri (self-advocades) dengan memiliki kemampuan berorganisasi serta kemampuan untuk kritis terhadap lingkungan sosial politik mereka. Penelitian lain yang dilakukan Alfirdaus (2020) memetakan peran perempuan, ibu rumah tangga dan petani perempuan, dalam menggalang gerakan perlindungan lingkungan. Dalam kajian perlawanan akar rumput di Indonesia yang dilakukan dalam rentang tahun 2018 sampai dengan tahun 2020 di sejumlah lokasi pertambangan seperti Rembang dan Pati di Jawa Tengah, Kotawaringin Barat, Lamandau dan Palangkaraya di Kalimantan Tengah, Belitung Timur di Kepulauan Bangka Belitung dan Balikpapan di Kalimantan Timur tersebut, Alfirdaus menemukan bahwa garda depan perlawanan dilakukan oleh perempuan petani dan ibu rumah tangga.

Temuan utama dari penelitian ini adalah adanya dua faktor utama yang memiliki sumbangan terhadap efektivitas gerakan, yaitu penggunaan jejaring dan kreativitas gerakan. Jejaring organisasi tingkat desa seperti PKK, Posyandu dan pengajian telah membentuk kemampuan berorganisasi para perempuan petani dan ibu rumah tangga ini. Aktivitas organisasi korporatis perempuan yang muncul di era Orde Baru ini bahkan kemudian menjadi ajang konsolidasi yang determinan. Efektivitas gerakan juga ditentukan oleh kreativitas bentuk gerakan yang dilakukan. Salah satu contoh yang terkenal adalah apa yang dilakukan oleh Aleta Baun yang membawa alat tenun mereka ke tengah-tengah lokasi penambangan marmer di Nusa Tenggara Timur, dan melakukan aktivitas menenun di situ. Studi tentang penambangan batu kapur dan lempung di Pegunungan Kendenga Utara juga dilakukan oleh Suharko (2013). Kajian yang menggunakan data sekunder ini bertujuan untuk memetakan konflik yang terjadi diantara PT. SMS dan komunitas sedulur sikep. Menurut Suharko berlum adanya upaya resolusi konflik yang baik menyebabkan belum terselesaikannya masalah ini.Suharko tidak menemukan strategi efektif yang bisa digunakan oleh gerakan anti semen. Pandangan serupa juga dikemukakan dalam penelitian tentang reklamasi di Teluk Benoa Bali (Hapsari, 2015).

Menurut Tilly (1977) kita bisa membedakan dua jenis gerakan akar rumput, yaitu gerakan proaktif yang bertujuan untuk menuntut hak-hak baru yang sebelumnya tidak mereka miliki, dan gerakan reaktif yang bertujuan untuk melawan agen negara demi mempertahankan hak-hak kelompok. Dinamika gerakan sosial akar rumput akhir-akhir ini tidak sepenuhnya dipahami. Kajian terhadap gerakan ini pada umumnya 
mengkategorikannya sebagai gerakan reaktif, dimana struktur kesempatan politik terjadi karena longgarnya pengawasan dari pemerintah. Oleh karenannya solusi yang perlu dilakukan adalah dengan memperbaiki perundangan terkait untuk memastikan adanya kepastian hukum. Namun cara pandang seperti ini tidak cukup menjelaskan mengapa kelompok masyarakat di suatu daerah lebih aktif dibandingkan daerah lain yang memiliki persoalan yang serupa. Kajian yang dilakukan Alfirdaus (2011, 2014, 2020) memang mulai memberikan perhatian kepada faktor internal gerakan, yaitu jejaring dan strategi gerakan. Kajian seperti ini perlu diperdalam dengan melihat aspek strategis dari jejaring itu sendiri. Kajian gerakan komunitas akar rumput menemukan bahwa jejaring sosial memiliki peranan determinan dalam mobilisasi tindakan kolektif (Opp \& Gern, 1993) . Dalam kajian ini jejaring horisontal diantara kelompok akar rumput memiliki peran yang penting. Kajian lain menunjukkan bahwa jejaring vertikal diantara kelompok akar rumput dan pejabat pemerintah seringkali juga merupakan faktor penting (Walder, 1986).

\section{Modal Sosial sebagai Dasar Gerakan Sosial}

Dalam pandangan Putnam, Leonardi, \& Nanetti (1994) seperti juga (Coleman, 1988), Bourdieu (1986) mendefinisikan modal sosial memakai dua komponen utama yaitu social network dan trust. Modal sosial merupakan wadah hubungan dan kegiatan sosial dari sebuah kelompok masyarakat. Modal sosial meliputi trust (kepercayaan), network (jejaring) dan norms (norma) sebagai pijakan hubungan diantara anggota masyarakat sehari-hari yang berkembang di dalam kelompok masyarakat sebagai bagian proses interaksi sosial yang terjadi. Elemen-elemen dalam modal sosial inilah yang menjadi sumber kekuatan bagi individu dalam suatu kelompok. Kekuatan modal sosial merupakan representasi elemen-elemen yang menjadi bagian tidak terpisahkan dalam struktur sosial kelompok. Dari sinilah suatu tindakan kolektif masyarakat bisa terjadi dalam suatu gerakan sosial.

Sebagai suatu lembaga sosial yang dibentuk dari adanya jejaring, norma-norma dan rasa saling percaya diantara individu dalam komunitas, modal sosial merupakan kekuatan untuk terjadinya kolaborasi sosial (koordinasi dan kooperasi) dalam komunitas. Untuk bisa menelisik lebih jauh ke dalam mekanisme kerja lembaga sosial ini, kita dapat memisahkan dua kategori yang saling berhubungan dalam modal sosial yaitu, (a) struktural dan (b) kognitif. Pada level struktural modal sosial berhubungan dengan berbagai bentuk organisasi sosial diantaranya role, rule, precedence, dan procedure, maupun network, yang memiliki kontribusi terhadap terjadinya kerjasama, utamanya collective action yang memiliki manfaat bersama (mutually beneficial collective action). Pada tataran kognitif proses mental dan pemikiran yang dihasilkan, diperkuat oleh budaya dan ideologi, menimbulkan tindakan kolektif untuk mencapai tujuan bersama (Nahapiet \& Ghoshal, 1998: 242).

Elemen organisasi sosial kategori pertama membuat biaya transaksi lebih rendah karena pola interaksi telah terbentuk sehingga hasil produktif yang didapatkan dari kerjasama lebih mudah diprediksi dan tentu saja sangat bermanfaat. Pemikiran pada kategori yang kedua mengkondisikan orang-orang terhadap tindakan kolektif, sebagian disebabkan ide yang telah dipamahi bersama (shared) sehingga membuat kerjasama sangat mungkin dilakukan. Rasionalisasi dari tindakan kolektif tersebut didapatkan dari nilainilai, sikap, norma, dan kepercayaan yang merupakan elemen modal sosial kognitif (Nahapiet \& Ghoshal, 1998: 242) 
Dua kategori modal sosial ini secara intrinsik terhubung karena meskipun jejaring bersama-sama dengan peran, nilai, sikap, preseden dan prosedur dapat dipahami dan bekerja secara mandiri, pada dasarnya elemen-elemen ini berasal dari proses kognitif. Aset-aset modal sosial kapital struktural dapat diobservasi, sedangkan aset-aset modal sosial kognitif tidak demikian.Dalam praktik sehari-hari kedua elemen ini terhubung oleh fenomena perilaku subyektif yang menjadi alasan bertindak yaitu harapan.

Untuk mendapatkan pemahaman lebih lanjut tentang modal sosial ilmuwan sosial membuat kategori yang sifatnya kontinyu terhadap modal sosial, yaitu bonding, bridging, dan linking. Modal sosial dalam kategori bonding dan bridging merupakan modal sosial yang didasarkan hubungan horisontal diantara orang-orang dengan status sosial dan politik yang sama (Putnam et al., 1994). Dalam pandangan Putnam hubungan horisontal tidak saja menghasilkan sesuatu yang memang diinginkan (desirable) tetapi juga hasil yang tidak diinginkan (undesirable). Modal sosial linking, merujuk kepada hubungan vertikal diantara orang-orang yang berinteraksi dalam struktur kewenangan dan kelembagaan dalam masyarakat (Szreter \& Woolcock, 2004: 6)

Modal sosial bonding merupakan jenis modal sosial berupa hubungan horisontal diantara individu dalam satu kelompok modal sosial yang sama. Modal sosial bonding ini terjadi dalam interaksi masyarakat setempat, dimana orang yang satu kenal dengan yang lain.Oleh karenanya masing-masing anggota memiliki akses kepada aset jejaring yang sama sehingga menimbulkan tingkat solidaritas yang tinggi. Dalam modal sosial bonding para anggotanya dipersatukan oleh norma-norma, adat kebiasaaan dan kepercayaan yang sama.

Modal sosial bridging merujuk kepada hubungan horisontal diantara individu dari satu modal sosial dengan modal sosial lain. Masing-masing bisa memanfaatkan sumber daya jejaring yang ada melalui struktur hirarki sosial yang ada. Dalam hubungan bridging ini tidak banyak norma-norma bersama. Lebih banyak melibatkan hubungan timbal balik yang terkait dengan kepercayaan yang tinggi diantara partisipan. Hubungan modal sosial bridging dapat memberikan akses individu kepada sumber daya di luar jejaring mereka sehingga manfaat yang didapat sangat signifikan.

Modal sosial linking berbeda dengan modal sosial bridging pada perbedaan kekuasaan diantara mitra. Kalau modal sosial bridging mengembangkan kepercayaan horisontal diantara kelompok-kelompok yang tidak sama, modal sosial linking melibatkan hubungan klasik seperti hubungan patron-client atau mentor-mentree. Jadi dalam modal sosial linking hubungan yang terjadi diantara individu atau kelompok dan kelompok atau individu yang berbeda strata sosialnya dalam suatu hirarki dimana kekuasaan, status sosial dan kesejahteraan diakses oleh berbagai kelompok modal sosial. Dengan demikian modal sosial ini terjadi pada individu yang membangun hubungan dengan lembaga atau individu yang memiliki kekuasaan atas dirinya (menyediakan akses pelayanan, pekerjaan atau sumberdaya). Hubungan linking juga melibatkan pola saling menguntungkan diantara pihak yang terlibat. Misalnya, pemberi pinjaman berharap pelayanan yang efektif serta berkualitas bagi bantuan yang mereka dapatkan, dan mentor berharap individu yang bekerja dengan mereka mengingat jasa yang telah mereka terima dengan hidup dengan layak atau menyediakan bantuan serupa untuk orang lain.

Modal sosial linking memiliki manfaat yang tidak langsung, misalnya menghubungkan pejabat pemerintah dengan individu-individu yang memiliki pengetahuan dan ketrampilan dalam menjalankan tugasnya. Modal sosial linking sangat penting untuk peningkatan kesejahteraan terutama di negara-negara dan komunitas miskin, dimana bank seringkali mematok tingkat bunga yang tinggi, polisi korup, guru 
membolos mengajar. Modal sosial jenis ini membuka kesempatan yang besar bagi kelompok yang terpinggirkan atau kelompok marjinal (Szreter \& Woolcock, 2004).

\section{Mobilisasi Perlawanan: Bagaimana Kesadaran Kolektif Muncul}

PT Sahabat Mulai Sakti (SMS) merencanakan pendirian pabrik semen di Kecamatan Tambakromo dan Kayen pada tahun 2010. Ada 11 desa yang rencananya bakal terkena dampak pendirian pabrik semen di Kecamatan Tambakromo dan Kayen. Desa-desa itu adalah Brati, Karangawen, Larangan, Pakis, Purwokerto, Sumbersari, Mojomulyo, Keben, Wukirsari, Tambakromo dan Maitan. Luas penambangan jika pabrik semen didirikan yaitu untuk batu gamping 2000 hektar, tanah liat 600 hektar dan luas pabrik sendiri 180 hektar. Pada kondisi lapangan, ada 64 goa dan ada 125 sumber mata air yang harus dilindungi di kawasan Pegunungan Kendeng. Sedangkan dampak terhadap lahan pertanian warga di Tambakromo ada seluas 4,56 hektar atau 80\% yang terkena dampaknya. Jumlah pemilik lahan yang tanahnya akan digunakan untuk pabrik semen sebanyak 569 orang, dengan rincian 129 pemilik di Mojomulyo, 151 pemilik lahan di Karangawen dan di Larangan sebanyak 154 orang. Desa Maitan sendiri, setidaknya akan ada 6.000 sekian jiwa ini akan merasakan dampak dari pembangunan pabrik semen. Belum lagi nantinya Maitan terkena dampak akibat lokasi tapak pabrik semen. Pabrik tersebut juga akan menggusur setidaknya 300 hingga 400 kepala keluarga. (Wawancara dengan S, 17 Februari 2018)

Proyek ini sangat merisaukan warga Maitan yang akan terganggu kedamaian kehidupan perdesaan mereka. Di samping itu pabrik tersebut juga akan memakan lahan yang luas yang tentu saja akan mengurangi wiayah pertanian Desa Maitan. Dengan adanya permasalahan tersebut, banyak dari warga Maitan yang tergugah hatinya untuk ikut memperjuangkan tolak pabrik semen. Sebut saja Pak Bagio, Pak Sakijan, Yu Patmen, Pak Sudam, Pak Wahyu, dan lainnya. Orang-orang tersebut kemudian berusaha untuk menggalang kekuatan dengan mengumpulkan persetujuan masyarakat Desa Maitan untuk bersama-sama melakukan protes agar pendirian pabrik semen dibatalkan. Banyak dari warga Maitan yang ikut bergabung dalam Jaringan Masyarakat Peduli Pegunungan Kendeng (JMPPK) yang bertujuan untuk menjaga Kendeng tetap lestari dan menolak keras pendirian pabrik semen.

Setiap anggota gerakan yang mempunyai kesadaran cinta lingkungan mempunyai tugas yang sama, yaitu menjaga kelestarian lingkungan atau alam. Namun, sebuah gerakan anti pabrik semen juga sadar bahwa adanya pemimpin sangat penting dalam tercapainya tujuan perlawanan. Maka disepakati untuk menunjuk Gunretno sebagai pimpinan JMPPK yang dikenal memiliki tingkat kepercayaan yang tinggi dan kemampuan yang mumpuni dari masyarakat (wawancara dengan bp.S,17 Februari 2018). Gunretno adalah tokoh Sedulur Sikep (Samin) yang berprofesi sebagai petani, tinggal di Dusun Bombong Desa Baturejo, Kecamatan Sukolilo, Kabupaten Pati Jawa Tengah. Para aktivis pergerakan anti pabrik semen percaya bahwa Gunretno merupakan seorang pemimpin yang memadai untuk memimpin perlawanan terhadap pendirian pabrik semen. Gunretno memiliki hubungan yang luas dengan masyarakat maupun orang-orang di jajaran pemerintahan yang akan sangat berguna dalam meningkatkan posisi tawar pergerakan ini di masa depan. Jaringan tersebut mulai dari awal berdiri hingga saat ini sudah menyebar di seluruh wilayah Pegunungan Kendeng (Pati, Rembang,Purwodadi,Blora). Di Kabupaten Pati sendiri, sebagian besar anggota JMPPK berasal dari wilayah Pati Selatan, seperti Kayen, Tambakromo dan Sukolilo. 
Masyarakat yang melawan pendirian pabrik semen menggugat surat keputusan Bupati Pati nomor 660.1/4767 Tentang Izin Lingkungan Pembangunan Pabrik Semen dan Penambangan Batu Gamping dan Batu Lempung di Kabupaten Pati oleh PT. Sahabat Mulia Saksi (SMS). Proyek pendirian pabrik semen tidak sesuai dengan Undangundang No.26/2007 tentang Penataan Ruang, Peraturan Pemerintah No.26/2008 tentang Rencana Tata Ruang Wilayah Nasional, Keputusan Menteri ESDM No. 0398 K/40/MEM/2005 tentang Penetapan Kawasan Karst Sukolilo dan Peraturan Menteri Lingkungan Hidup No.16/2012 tentang Pedoman Penyusunan Dokumen Lingkungan Hidup dan bertentangan dengan gagasan good governance.

Masyarakat yang menolak pendirian pabrik semen, khususnya yang ada di Desa Maitan, percaya bahwa jika mereka bisa menemukan bukti yang memperkuat bahwa pihak pabrik semen telah melanggar peraturan tersebut dan nantinya akan menyebabkan kerusakan alam di Desa Maitan, mereka bersama-sama dengan anggota Peduli Kendeng lainnya bisa mendesak pemerintah (dengan menggunakan koneksi di pemda/pemprov) untuk menghentikan proyek tersebut. Oleh karena itu para pegiat Peduli Kendeng yang ada di Maitan berusaha untuk mengumpulkan bukti yang kuat dengan menggunakan jejaring personal yang mereka miliki. Mereka juga berupaya menggunakan koneksinya yang luas untuk bergabung dengan gerakan kontra pendirian pabrik semen untuk membentuk kekuatan kolektif yang lebih besar. Dua hal yang penting bagi suatu gerakan akar rumput dengan demikian adalah pemahaman tentang regulasi yang berhubungan dengan masalah yang sedang dihadapi dan kemampuan relasi publik yang baik. Meskipun sebenarnya, regulasi bagi kelompok perlawanan ini hanya digunakan sebagai pijakan legitimasi gerakan mereka dan untuk menekan pemerintah, sedangkan modal sosial menjadi alat utama bagi mereka dalam membangun kelompok perlawanan.

Melihat pergerakan jaringan yang masif, banyak masyarakat Maitan yang ikut sadar dan tergerak untuk bersama-sama melawan pendirian pabrik semen. Karena, nantinya mereka sendiri pula yang ikut terkena dampak dari pendirian pabrik semen tersebut. Banyak warga Maitan bersedia bergabung dengan gerakan anti pabrik semen dan menjadi pendukung loyal selama gerakan ini berjalan. Di samping itu, ada pejabat pemerintah yang memberikan cetak biru pengembangan wilayah kepada kelompok warga Maitan dengan diam-diam. Berdasarkan cetak biru tersebut Desa Maitan termasuk dalam wilayah konservasi yang tidak boleh ditambang.

\section{Membangun Tindakan Kolektif: Belajar dari Kegagalan}

Sejak awal PT SMS mengadakan sosialisasi pembangunan pabrik semen pada tahun 2010, masyarakat Maitan secara tegas menyatakan menolak pendirian pabrik semen. Dengan didukung JMPPK masyarakat Desa Maitan meminta dengan keras kepada Bupati untuk mencabut izin lokasi yang telah diberikan kepada PT SMS. Mereka juga menghalang-halangi proses penyusunan AMDAL yang dilakukan PT.SMS dengan cara menutup akses tim penyusun AMDAL di lapangan. Tentu saja upaya penolakan ini sangat menyulitkan PT.SMS untuk dapat segera menyusun AMDAL sebagai dasar untuk mendapatkan izin lingkungan dari pemerintah.

Dari dokumen AMDAL yang dihasilkan dapat diketahui bahwa masyarakat menolak pendirian pabrik semen. Bambang Sutikno salah satu aktivits JMPPK mengatakan bahwa AMDAL seharusnya dibatalkan, karena dalam dokumen AMDAL tersebut dikatakan bahwa $67 \%$ anggota masyarakat menolak pabrik semen. Hanya 20\% yang menyatakan setuju, sedangkan sisanya tidak menentukan sikap. Namun komisi penilai AMDAL tidak mempermasalahkan penolakan masyarakat tersebut dan setuju 
dengan kesimpulan dokumen AMDAL bahwa keberadaan pabrik semen yang direncanakan tersebut telah memenuhi persyaratan kelayakan lingkungan. Dengan dasar pertimbangan tersebut diterbitkan Surat Keputusan Kelayakan Lingkungan (SKKL) No 660.1/4766 tahun 2014 berikut rekomendasi bernomor 660.1/012/XII/Amdal/2014. Dua surat keputusan ini menjadi acuan bagi Bupati untuk menerbitkan izin lingkungan pendirian pabrik semen oleh PT SMS.

Terbitnya izin lingkungan ini merupakan kekalahan yang menyakitkan bagi masyarakat penolak pendirian pabrik semen. Aksi yang lebih masif dilakukan yang dikoordinasikan oleh JMPPK. Aksi ini dilakukan pada 3 Oktober 2004. Pada aksi ini masyarakat melakukan rembug warga sehari penuh yang membahas kedaulatan pangan. Untuk memberikan penekanan yang lebih kuat pada rembug warga tersebut juga diikuti ritual lamporan (Wawancara dengan bp.BJ tg 2 April 2018). Ritual lamporan secara adat dilakukan masyarakat untuk mengusir lampor yang merupakan personifikasi dari kekuatan hitam. Kekuatan hitam ini dipercayai muncul dalam bentuk hama yang merusak tanaman serta berbagai penyakit yang mengancam kehidupan masyarakat (wawancara dengan bp.J tg 2 April 2018). Jelas sekali lamporan kali ini mempersonifikasikan pabrik semen sebagai kekuatan hitam yang mengancam kehidupan mereka.

Masyarakat yang hadir dalam lamporan tersebut mayoritas petani dari kawasan Pegunungan Kendeng Utara (Pati, Purwodadi, Blora, Rembang). Gema perlawanan ini terbukti telah sampai ke telinga banyak orang di luar Pati terbukti dengan hadirnya warga yang datang dari kawasan karst Maros-Pangkep, Sulawesi Selatan. Laki-laki, perempuan, anak-anak hingga dewasa, antusias mengikuti ritual tersebut (wawancara dengan bp.J tg 2 April 2018). Keragaman pendukung kelompok penolak pabrik semen tampak dari penampilan mereka yang sangat beragam. Nampak hadir wanita-wanita yang mengenakan hijab, wanita dengan kebaya tradisional, pria bercelana cekak berkopiah, pria berkopiah dan bersarung, pria yang mengenakan surjan hitam bercelana komprang dan memakai ikat kepala udeng. Perhelatan ini juga mampu menarik perhatian sejumlah tokoh nasional seperti Alissa Wahid (putri mantan Presiden Abdurrahman Wahid) dan Bondan Gunawan (mantan Mensesneg).

Meskipun begitu besar penolakan pendirian pabrik semen yang juga didukung tokoh tokoh nasional, tetap saja Bupati menerbitkan SK izin lingkungan. Pada Desember 2014, terbit Surat Keputusan (SK) Bupati Pati Nomor: 660.1/4767/2014 yang memuat izin lingkungan pabrik semen dan penambangan batu gamping dan batu lempung kepada PT SMS. SK ini merupakan tahap akhir dari proses penyusunan dokumen AMDAL yang sudah dilakukan sejak 2011. Berdasar pemberian izin lingkungan ini, secara hukum, PT SMS diperkenankan untuk melakukan pendirian konstruksi pabrik semen. Makna dari keluarnya izin lingkungan ini adalah kekalahan masyarakat Kendeng dan JMPPK dari PT.SMS

Kegagalan menghalangi terbitkanya surat ijin lingkungan direspon dengan pendekatan legal. Pada tahun 2015 sekelompok masyarakat Kendeng, Jasmo, Warjo, Paini, Samiun dan Sarjudi mengajukan gugatan ke PTUN Semarang. Tuntutan mereka adalah pembatalan SK Bupati Pati No: 660.1/4767 tahun 2014 tentang Izin Lingkungan Pembangunan Pabrik Semen serta Penambangan Batugamping dan Batu lempung oleh PT SMS. Mereka mendaftarkan Gugatan ini didaftarkan ke PTUN pada 4 Maret 2015. Proses persidangan terhambat pelaksanaanya karena adanya beberapa perbaikan yang berkaitan dengan kronologis munculnya surat izin lingkungan Bupati. Sambil menunggu pelaksanaan sidang beberapa warga Pati menghadap Gubernur Jateng Ganjar Pranowo. 
Mereka mengeluhkan Bupati Pati yang mereka anggap tidak mempertimbangkan aspirasi masyarakat tentang pendirian pabrik semen di daerah Kendeng Utara. Ganjar Pranowo sebagai Gubernur Jateng diharapkan mau berkunjung ke desa-desa yang menjadi tapak pendirian pabrik semen. Mereka ingin Gubernur Ganjar mengetahui kondisi desa-desa yang menjadi tapak pendirian pabrik semen.

Ratusan warga dari daerah yang menolak pendirian pabrik semen di wilayah Pegunungan Kendeng Utara berjalan kaki dari Sukolilo Kabupaten Pati sampai PTUN Semarang, sepanjang 122 KM, menjelang sidang PTUN. Long March protest ini dilakukan setelah mengikuti Lamporan pada Minggu malam tanggal 15 November. Long March ini terkenal dengan sebutan "Kendeng Menjemput Keadilan". Aksi ini diikuti dengan aksi di media sosial, melalui berbagai tagar, salah satunya adalah \#Menjemput Keadilan. Warganet dengan demikian ikut serta mendukung aksi JMPPK melalui media sosial. Melalui Twitter, Path hingga Facebook masyarakat yang bersimpati kepada gerakan ini dengan mudah bisa bergabung dalam mendukung aksi yang dilakukan masyarakat Kendeng dan JMPPK. Keputusan Hakim PUTN dibacakan pada tanggal 17 November 2015. Hasil putusan PUTN mengabulkan gugatan warga. Dengan demikian SK Bupati Pati Nomor 660.1/4767/2014 tertanggal 8 Desember 2014 tentang Izin Lingkungan Pembangunan Pabrik Semen dan Penambangan Batu Gamping dan Lempung oleh PT SMS dibatalkan. Pertimbangan Hakim PUTN Hakim dalam mengambil keputusan adalah kesesuaian lokasi pabrik semen dengan dokumen Rencana Tata Ruang dan wilayah (RTRW) dan asas umum penyelenggaraan pemerintahan yang baik. Hakim juga berpendapat bahwa proses AMDAL seharusnya melibatkan masyarakat sekitar yang terkena dampak pembangunan pabrik semen tersebut. Itu tidak dilakukan. Sayang sekali keputusan yang memenangkan masyarakat Kendeng ini pada akhirnya dipatahkan melalui keputusan pengadilan banding PTTUN Surabaya. Putusan hakim PTTUN Surabaya tertanggal 1 Juli 2016 dan dibacakan pada 14 Juli 2016 memenangkan banding PT SMS dan Bupati Pati. Dengan demikian putusan PTUN Semarang bernomor register 015/G/2015/PTUN.SMG, tertanggal 17 November 2015, yang memenangkan gugatan masyarakat Kendeng yang menolak Izin Lingkungan yang diberikan kepada PT SMS oleh Bupati Pati, dibatalkan.

\section{Tumbuhnya Modal Sosial dan Upaya Mempermalukan Bupati}

Pada pertengahan Desember 2017, ratusan massa JMPPK melakukan aksi unjuk rasa didepan halaman kantor Bupati Pati. Mereka mununtut agar pemerintah tidak menyetujui perpanjangan ijin PT. SMS karena ijinnnya sudah habis terhitung mulai tanggal 8 Desember 2017. Setidaknya, dalam setahun masyarakat Maitan dan warga Kendeng lainnya tidak lagi diresahkan oleh adanya upaya pendirian pabrik semen.

Fase pertama dari gerakan masyarakat ini sangat berpengaruh terhadap hubungan sosial diantara masyarakat Maitan. Pertama, keberhasilan perlawanan kolektif meningkatkan rasa saling percaya diantara anggota masyarakat. Gunretno sebagai pemimpin yang sukses membangun perlawanan kolektif juga mendapatkan kepercayaan yang tinggi dari masyarakat. Gerakan perlawanan juga meningkatkan interaksi yang terjadi diantara warga masyarakat dan sekaligus rasa saling percaya diantara mereka yang terlibat dalam gerakan tersebut. Kedua, dalam proses perlawanan ini, jejaring informal diantara para aktivis gerakan mulai muncul dalam komunitas Maitan.

Hampir di setiap dusun terdapat aktivis dari berbagai kalangan, gender, dan identitas politik. Jejaring informal ini memudahkan memobilisai masyarakat untuk melakukan gerakan kolektif. Pada tahun 2008 dibentuk organisasi resmi yang menaungi 
kegiatan kemasyarakatan kelompok perlawanan ini. Ketiga, seringnya perlawanan kolektif dilakukan telah mendorong terbentuknya norma-norma partisipasi. Keberhasilan gerakan perlawanan meyakinkan anggota masyarakat lain bahwa perlawanan kolektif tidak membahayakan hidup mereka. Ini menjadi ingatan kolektif dari masyarakat Maitan. Tradisi untuk mempertahankan hak-hak hidup mereka berdasarkan hukum yang berlaku mulai dibangun. Sejajar dengan itu mayoritas warga mulai menganggap berpartisipasi dalam gerakan perlawanan membela hak-hak hidup mereka merupakan tugas mulia. Utamanya, Gunretno melalui berbagai jalur berhasil mendapatkan kepercayaan dan dukungan dari media massa dan pejabat tinggi di kabupaten/provinsi, dan pada gilirannya ia mulai membangun hubungan personal dengan beberapa pejabat dan wartawan.

Dengan demikian perlawanan kolektif yang berlangsung secara terus menerus telah memberikan kontribusi terhadap peningkatan modal sosial individual dan pemimpin gerakan, serta modal sosial kolektif dalam masyarakat Maitan. Ini pada gilirannya menjadi dasar dari kerjasama antar warga di masa mendatang. Rasa saling percaya dan jejaring diantara warga masyarakat, serta norma partisipasi dalam masyarakat merupakan modal sosial bonding, sedangkan hubungan vertikal diantara aktivis perlawanan dan pejabat kabupaten/provinsi serta wartawan dan aktivis di level yang lebih tinggi ini merupakan modal sosial linking.

Perlawanan yang terjadi disadari oleh para aktivis akan sangat berbeda dengan perlawanan terhadap pabrik semen. Kali ini yang mereka hadapi adalah kekuasaan yang kuat dari kabupaten. Namun demikian, secara simbolik masyarakat ingin mempermalukan kekuatan kekuasaaan dan uang dari kabupaten. Untuk menghilangkan rasa takut dalam mengekspresikan ketidakpuasan mereka kepada bupati petahana, para aktivis secara komrpehensif menjelaskan hak-hak warga untuk tidak mendukung bupati yang tidak memberikan kebijakan yang pro rakyat.

Bupati Pati kebijakannya dianggap tidak pro-lingkungan dan masyarakat kecil. Masyarakat menilai bahwa Bupati Haryanto mengingkari janjinya dalam kampanye Pilkada 2012, yaitu janji untuk tidak memberi ijin pendirian pabrik semen. Janji itu diingkari dengan terbitnya surat keputusan Bupati Pati nomor 660.1/4767 tentang Izin Lingkungan Pembangunan Pabrik Semen dan Penambangan Batu Gamping dan Batu Lempung di Kabupaten Pati oleh PT. SMS.

Pilkada Kabupaten Pati 2017 hanya diikuti oleh satu pasangan calon, yaitu Haryanto yang sebagai petahana berpasangan dengan Saiful Arifin. Dalam menjawab kritikan terhadap kebijakanya tentang pendirian pabrik semen, pasangan HaryantoSaiful Arifin menekankan bahwa setiap kebijakan pasti memiliki aspek pro dan kontra. Dalam setiap kebijakan pembangunan selalu ada korban yang harus direlakan demik terwujudnya pembangunan untuk kebaikan masyarakat Pati secara keseluruhan.Ia selalu menghindar konfrontasi secara langsung dengan JMPPK. Dengan demikian dialog antara calon Petahana dan masyarakat tidak pernah terjadi.

Untuk memuluskan pencalonannya, bupati petahana memobilisasi segala sumberdaya untuk mendapatkan dukungan 8 partai politik, yaitu PDIP, Golkar, PKB, PKS, Gerindra, PPP, Demokrat, dan Hanura. Dengan dukungan yang mayoritas partai politik tersebut, bupati petahana merasa aman meski ada perlawanan dari masyarakat yang tidak menginginkannya untuk terpilih kembali.

Sebagai upaya untuk menghalang-halangi terpilihnya Bupati Petahana Haryanto terpilih kembali masyarakat Pati Selatan, khususnya desa Maitan berbondong-bondong 
mendeklarasikan diri untuk menolak bupati petahana. Masyarakat menilai petahana tidak layak untuk melanjutkan kepemimpinannya yang tidak pro rakyat.

Pada masa menjelang pilkada Kabupaten Pati, sebuah organisasi masyarakat sipil terbentuk. AKDPP (Aliansi Kawal Demokrasi Pilkada Pati) memiliki tujuan yang sama dengan masyarakat Desa Maitan, yaitu tidak menginginkan Haryanto untuk berkuasa kembali. Alasan AKDPP untuk menggusur bupati petahana didasarkan pada pendapat bahwa calon tunggal tidak sesuai dengan asas kompetisi dalam proses demokrasi. AKDPP menganggap bahwa partai politik telah gagal melakukan kaderisasi dan pendidikan politik. Upaya bupati petahana untuk menjadi calon tunggal dengan cara memobilisasi dukungan dari semua partai politik yang ada, merupakan upaya yang mengingkari etika demokrasi. Oleh karenanya harus ditolak untuk berkuasa kembali. Untuk memperoleh dukungan dari masyarakat, AKDPP menggunakan media sosial, terutama facebook. AKDPP mempunyai grup dengan nama "Relawan Kotak Kosong Pati Bumi Mina Tani" yang memiki anggota 4,3 ribu dan "Relawan Kotak Pati" yang memiliki jumlah anggota 4,5 ribu. Banyak dari masyarakat yang menyuarakan keluh kesah maupun penilaiannya terhadap kepemimpinan Haryanto. Melalui grup facebook ini pula banyak masyarakat Pati yang mengunggah gambar amplop berisikan uang dugaan hasil money politics. AKDPP juga mengadakan musyawarah terbuka, memberikan bantuan kepada korban bencana di Pati, dan menyelenggarakan pentas kesenian, dan sekaligus mengajak warga memilih kotak kosong.

Kesamaan tujuan ini yang membuat masyarakat Desa Maitan menggbungkan diri dengan AKDPP. Dengan mengadakan aliansi dengan AKDPP masyarakat Desa Maitan dan Kendeng Utara berupaya untuk memperluas jangkauan kampanye anti bupati petahana. Namun demikian, sebetulnya tindakan untuk bergabung dengan AKDPP menodai kemurnian gerakan anti pabrik semen di Maitan. Dengan bergabung dengan gerakan politik maka kekuatan moral gerakan anti pabrik semen menjadi melemah. Kredo gerakan yang membawa aspirasi rakyat untuk mempertahankan hakhak komunal mereka menjadi tidak sekuat pad awal gerakan. Ini yang menyebabkan melemahnya trust diantara peserta gerakan anti pabrik semen.

\section{Penutup}

Penelitian ini berusaha untuk menerapkan teori-teori modal sosial dalam upaya untuk menjelaskan apa yang terjadi dalam proses gerakan perlawanan masyarakat Desa Maitan Kabupaten Pati terhadap pembangunan pabrik semen. Teori-teori gerakan sosial yang biasa digunakan seperti teori mobilisasi sumberdaya dan proses politik tidak cukup dapat menerangkan bagaimana masyarakat Desa Maitan yang merupakan masyarakat petani bisa menjadi militan dan mampu memenangkan perlawanan terhadap korporasi. Persoalan ketidakcocokan teori-teori ini lebih disebabkan konteks sosial poltik yang berbeda diantara masyarakat liberal barat dan masyarakat pertanian di Indonesia yang sedang mengalami proses demokratisasi. Kasus di Kabupaten Pati, terutama Desa Maitan, mengingatkan peneliti untuk lebih jeli dalam mengamati dan melakukan analisis sosial politik. Gerakan protes petani terhadap pemerintah dan pabrik semen di Desa Maitan bisa dijelaskan dengan menggunakan konsep modal sosial. Jejaring sosial sangat bermanfaat dalam mendorong terjadinya mobilisasi tindakan kolektif. Peran modal sosial horisontal diantara para petani dan masyarakat sekitar tidak akan terlalu berhasil kalau tidak didukung jejaring vertikal yang didapatkan melalui dukungan pejabat di birokrasi pemda, Pati maupun Jateng. Namun, kemurnian gerakan menjadi terganggu dengan bergabungnya gerakan anti pabrik semen dengan AKDPP. 


\section{Ucapan Terima Kasih}

Terima kasih kepada mahasiswa Ilmu Pemerintahan yang telah turut terlibat dalam penelitian lapangan.

\section{Pendanaan}

Penulis mendapat bantuan pembiayaan untuk penelitian dari dana DIPA Fakultas Ilmu Sosial dan Ilmu Politik Universitas Diponegoro 2018.

\section{Daftar Pustaka}

Alfirdaus, L. K. (2011). Ekonomi Politik Konflik Negara Versus Masyarakat (Studi Kasus Kebumen Selatan Paska 2005). Penelitian Dipa Fisip Undip Tidak Dipublikasikan.

Alfirdaus, L. K. (2014). To Be Self Advocates: How Southeast Asian Coutries Can learn from Three Indonesian Areas' Experiences in Dealing with Extractive Industries. In E. Fitrian, F. Seda, \& M. Yesi (Eds.), Governance of Extractive Industries:Assesing National Experiences to Informs Regional Cooperation in South East Asia. UI Press:Institute for Social Service Reforms.

Alfirdaus, L. K. (2020). Ibu Rumah Tangga dan Petani Perempuan Berperan Vital Dalam Pergerakan Lingkungan Indonesia. The Conversation bulan Maret.

Aspinall, E. (2014). Indonesia's 2014 Elections: Parliament and Patronage. Fournal of Democracy, 25(4), 96-110.

Bourdieu, P. (1986). The forms of capital.

Coleman, J. S. (1988). Social Capital in The Creation of Human Capital. American Fournal of Sociology, 94, S95-S120.

Fealy, G. (2013). Indonesian Politics in 2012: Graft, Intolerance, and Hope of Change in the Late Yudhoyono Period. Southeast Asian Affairs, 103-120. Retrieved from https://www.jstor.org/stable/23471139

Giddens, A. (1998). Conversations With Anthony Giddens. Making Sense of Modernity. Stanford University Press.

Hapsari, N. K. A. I. (2015). Regulasi Tanpa Basic SumberDaya Alam dan Lingkungan Sosial (Studi Penerapan Peraturan Presiden Nomor 51 Tahun 2014 tentang Perubahan Atas Peraturan Presiden Nomor 45 Tahun 2011 tentang Rencana Tata Ruang Kawasan Perkotaan Denpasar, Badung, Gianyar, dan T. Kumpulan Furnal Mahasiswa Fakultas Hukum, 1(1).

McAdam, D. (1996). Conceptual Origins, Current Problems, Future Directions. Comparative Perspectives on Social Movements: Political Opportunities, Mobilizing Structures, and Cultural Framings, 23-40.

Nahapiet, J., \& Ghoshal, S. (1998). Social Capital, Intellectual Capital, and The Organizational Advantage. Academy of Management Review, 23(2), 242-266.

Opp, K.-D., \& Gern, C. (1993). Dissident Groups, Personal Networks, and Spontaneous Cooperation: The East German Revolution of 1989. American Sociological Review, 659-680.

Putnam, R. D., Leonardi, R., \& Nanetti, R. Y. (1994). Making Democracy Work: Civic Traditions in Modern Italy. Princeton university press. 
Stake, R. E. (1994). "Case Studies" dalam Norman K.Denzin dan Yvonna S.Lincoln (eds.), Handbook or Qualitative Research. London: Sage Publication.

Suharko, S. (2013). Karst: Ditambang atau Dilestarikan, Konflik Sosial Rencana Pembangunan Pabrik Semen di Kabupaten Pati Jawa Tengah. Furnal Ilmu Sosial Dan Ilmu Politik, 17(2), 163-179.

Szreter, S., \& Woolcock, M. (2004). Health By Association? Social Capital, Social Theory, and The Political Economy of Public Health. International Fournal of Epidemiology, 33(4), 650-667.

Tilly, C. (1977). From Mobilization to Revolution.

Walder, A. G. (1986). Communist Neo-Traditionalism: Work and Authority in Chinese Industry. Univ of California Press.

\section{Tentang Penulis}

Priyatno Harsasto adalah dosen di Departemen Politik dan Pemerintahan, Fakultas Ilmu Sosial dan Ilmu Politik, Universitas Diponegoro, memiliki area riset di bidang bisnis dan politik, komunikasi politik, modal sosial dan gerakan sosial. 